Canadian University Music Review

Revue de musique des universités canadiennes

\title{
Edward T. Cone. The Composer's Voice. Berkeley: University of California Press, 1974; paperback edition 1982, ix, 184 pp.
}

\section{Robert Falck}

Numéro 4, 1983

URI : https://id.erudit.org/iderudit/1013910ar

DOI : https://doi.org/10.7202/1013910ar

Aller au sommaire du numéro

Éditeur(s)

Canadian University Music Society / Société de musique des universités

canadiennes

ISSN

0710-0353 (imprimé)

2291-2436 (numérique)

Découvrir la revue

Citer ce compte rendu

Falck, R. (1983). Compte rendu de [Edward T. Cone. The Composer's Voice. Berkeley: University of California Press, 1974; paperback edition 1982, ix, 184 pp.] Canadian University Music Review / Revue de musique des universités canadiennes, (4), 333-334. https://doi.org/10.7202/1013910ar

(C) Canadian University Music Society / Société de musique des universités canadiennes, 1983
Ce document est protégé par la loi sur le droit d'auteur. L'utilisation des services d'Érudit (y compris la reproduction) est assujettie à sa politique d'utilisation que vous pouvez consulter en ligne.

https://apropos.erudit.org/fr/usagers/politique-dutilisation/ 
habile une série de problèmes fondamentaux en ethnomusicologie. La diversité des approches méthodologiques, la finesse et le raffinement de ses analyses, un échantillonnage imposant de données, la démonstration de l'efficacité d'un nouvel outil analytique : l'ordinateur, une nouvelle démarche analytique, tous ces éléments en font une œuvre originale et intéressante que nous ne pouvons que conseiller à l'ensemble des personnes préoccupées d'analyses musicales dans leur contexte socio-culturel. Un travail donc de première importance dans la littérature ethnomusicologique.

Monique Desroches

EDWARD T. CONE. The Composer's Voice. Berkeley: University of California Press, 1974; paperback edition 1982, ix, 184 pp.

This paperback is a re-issue of Cone's revised 1972 lectures delivered as Ernest Bloch Professor of Music at the University of California. Thus the material is not new, and the book has already been reviewed extensively following its original publication. Still, the appearance of a paperback edition justifies a fresh look, and a fresh opportunity to stress for a new potential audience the value of Cone's first systematic treatise on a subject that has been at the center of his concern for over thirty years: music as communication between and among human beings. In the rigid system of classification familiar to readers of this journal, Cone is normally called a theorist rather than a musicologist, though his writings on analysis have always transcended the rather narrow and bloodless image conveyed by that term. He would be best described as a critic if that perfectly respectable appellation had not already been preempted by the mass circulation concert reviewers. Perhaps Cone and those who admire his work would be satisfied with a sui generis classification, and, indeed, he is without peer and virtually without competition among serious students of both old and new music who are convinced that it does communicate more than an Ursatz or a pitch-class set complex. As my own bias will be quite evident by now, let me say plainly that this is a book that can be read for pleasure and profit by any musician, and should be required reading for any serious performer.

Cone begins by asking "if music is a language, then who is speaking" (p.1)? This sets the stage for the first four chapters-virtually half of the book-which expound a theory of "voices" or personae lurking in virtually every genre of vocal music. A highlight is his discussion of Schubert's Erlkönig in Chapter I. This is a demonstration of principles to be applied to opera, the madrigal, the polytextual motet, and what the author calls "simple song" (a "song without accompaniment... 
[or an] accompaniment that has no individuality" [p.58] and thus no persona).

In his analysis of Erlkönig, Cone makes a convincing case that while a poem may imply several voices (here a narrator, or interlocuter and responder, and father, child, and erlking), the composer may impose his own "voice" upon that of the poet, or those of the poem. This view of vocal music is then applied to composers and compositions as diverse as Mozart, Schütz, Campion, Wagner, the American "pop" song "Happy Birthday to You," and The Rake's Progress. Perhaps this reviewer's own biases are responsible, but the sections dealing with early music seem the least successful and peruasive. He gets around the problem of a single musical persona in the madrigal, for instance, by invoking the notion that the singers are "reading" the pre-composed text rather than inventing it and experiencing it spontaneously as in the nineteenthcentury art song and most opera. This is an ingenious and useful distinction, and one which is also invoked to explain what takes place in the performance of sacred texts. (A telling point is made by contrasting this kind of performance with the familiar pseudo-dramatic setting of "The Lord's Prayer" by Albert Hay Malotte, pp. 52-53.) There is likewise a brief attempt to characterize the medieval polytextual motet in these terms. What Cone offers in lieu of a solution is probably as close as one can come. "Perhaps", he admits, "it is not heard in the sense that we are accustomed to" (p.67).

The second half of the book finally ventures into instrumental music, with a "Lesson from Berlioz" (Chapter V). Here the dramatic figures and personae of vocal music become virtual agents. It is symptomatic that Cone chooses the most characteristic kind of Romantic compositions as paradigms for his point of view. Just as Schubert's Erlkönig was used as a model demonstration for vocal music, so Berlioz's Symphonie Fantastique and Harold en Italie do the same for instrumental music. The coverage of instrumental music is not as comprehensive or as broad, but, in addition to Berlioz, Beethoven, Mahler, Carter, Bach, Brahms, and Giovanni Gabrieli all make at least cameo appearances.

The final chapters present some of the implications for both analysis and performance of considering both the context and the content of music. While Cone admits in the Epilogue that the foregoing was "meant to be prefatory to any theory of musical meaning or musical expression" (p.159), these final chapters offer many valuable insights into individual pieces and maintain a consistent point of view on the interrelationship between listening, performance, and analysis. When he says that ". . . the aim of music is to provide intense experiences, not structures for contemplation" (p.147), he stakes out a clearly anti-formalist position. This reader is inclined to allow a bit more room for contemplation, but for the performer and the listener, Cone's priorities are unquestionably the right ones.

Robert Falck 